\title{
Cellular Mechanisms in Regulating Mammary Cell Turnover During Lactation and Dry Period in Dairy Cows
}

\author{
J. V. Nørgaard, P. K. Theil, M. T. Sørensen, and K. Sejrsen ${ }^{1}$ \\ Department of Animal Health, Welfare and Nutrition, University of Aarhus, PO Box 50, DK-8830, Tjele, Denmark
}

\begin{abstract}
The mechanisms involved in regulating mammary cell turnover during the pregnancy-lactation cycle in dairy cows are unclear. The objective of present experiment was to describe expression of genes encoding proteins known to be involved in pathways regulating mammary cell proliferation, apoptosis, differentiation, cell survival, and tissue remodeling. Mammary gland biopsies were taken 7 times during the pregnancy-lactation cycle of 10 dairy cows, and samples were analyzed by immunohistochemistry and real-time PCR. Cell proliferation was greatest during the dry period and apoptosis was high in early dry period and early lactation. Based on Fas (tumor necrosis factor receptor superfamily member 6), Fas ligand, and caspase-3, caspase-8, and caspase-9 gene expression, no indication was found of a stage-dependent shift between the extrinsic and intrinsic pathways leading to apoptosis. Gene expression of microsomal glutathione S-transferase (mGST) did not vary significantly, whereas Bcell leukemia/lymphoma 2 (Bcl-2) and BCL2-associated $\mathrm{X}$ protein (Bax) gene expression was greatest during the dry period and early lactation and coincided with high cell turnover. Gene expression of early response genes c-Fos, c-Jun, and c-Myc correlated to neither rate of cell proliferation nor plasma concentration of insulinlike growth factor (IGF)-I and insulin. Gene expression of nuclear factor of kappa light chain gene enhancer in B-cells $(\mathrm{NF} \kappa \mathrm{B})$ and $\mathrm{NF} \kappa \mathrm{B}$ inhibitor $\alpha$ was greatest in the periparturient period, and $\mathrm{NF} \kappa \mathrm{B}$ gene expression coincided with an anticipated need for cell survival factors. Expression of transforming growth factor $\beta$ (TGF$\beta$ ) receptor 1 and 2 mRNA was greatest in early lactation, whereas TGF- $\beta 1$ did not vary significant during the pregnancy-lactation cycle. Even though our results on the TGF- $\beta$ system did not comply with other studies, the gene expression pattern of the TGF- $\beta$ receptors indicates a role in regulating apoptosis in early lactation.
\end{abstract}

Received October 10, 2007.

Accepted February 6, 2008.

${ }^{1}$ Corresponding author: Kr.Sejrsen@agrsci.dk
Signal transducer and activator of transcription 5 (STAT5) gene expression was high in the periparturient period, which suggests a role for STAT5 in regulation of mammary cell proliferation and differentiation in dairy cows. Expression of tissue-plasminogen activator, plasminogen activator inhibitor-1, and IGF binding protein 5 genes was greatest in early lactation, suggesting a role for IGF binding protein 5 in coordinating regulation of apoptosis and tissue remodeling.

Key words: mammary cell turnover, proliferation, apoptosis, dairy cow

\section{INTRODUCTION}

Recent studies have quantified mammary cell turnover in dairy cows (Capuco et al., 2001; Sørensen et al., 2006), but the mechanisms regulating apoptosis and cell proliferation during the lactation and pregnancy cycle are still unknown.

Controlled cell death in the bovine mammary gland is mediated by apoptosis and, to a lesser extent, autophagy (Zarzynska et al., 2007). There are 2 major pathways leading to apoptosis: an extrinsic and an intrinsic pathway. The extrinsic pathway is induced by activation of death receptors located on the cell surface. The intrinsic pathway of apoptosis involves the mitochondria and can be triggered by intracellular stressors such as oxidants, and a variety of proteins are involved in maintaining a stable intramitochondrial environment and membrane integrity (Fernandez-Checa, 2003). Changes in the intrinsic pathways of apoptosis may, therefore, be of importance in maintaining cell number.

Cell proliferation is the other major determinant of cell turnover. Although mammary cell proliferation during established lactation is low (Sørensen et al., 2006), it is not insignificant in relation to maintaining cell number. We have previously shown that feed intake (Nørgaard et al., 2005) and pregnancy status (Nørgaard et al., 2008) can affect mammary cell proliferation. The level of systemic and mammary expressed growth factors during lactation and pregnancy cycle are well described, but it is still not clear how growth factors affect expression of transcription factors initiating cell cycle progression. 
It is generally accepted (Capuco et al., 2001) that the increasing milk yield until peak lactation is due to increased differentiation of mammary tissue. Cellular processes in tissue remodeling and differentiation in mammary glands of cows in consecutive lactations are, to our knowledge, not described.

The objective of the present experiment was to investigate expression of genes known to mediate effects on pathways involved in regulation of mammary cell turnover, differentiation, and tissue remodeling. We have chosen to focus on factors that are potentially important for normal mammary development, function, and in maintaining lactation persistency; that is, pathways leading to apoptosis, growth factor signaling, differentiation, and tissue remodeling. The objective was addressed by taking mammary biopsies throughout the lactation and pregnancy cycle in dairy cows, and evaluating mRNA abundance.

\section{MATERIALS AND METHODS}

\section{Animals and Diets}

The present paper is a follow-up to the study presented in Sørensen et al. (2006). Ten Holstein-Friesian cows in first to fourth parity were used in the study. They were all handled according to standard procedures. The cows were housed in tie-stalls, milked daily at approximately 0600 and $1600 \mathrm{~h}$, and fed a ration based on grass silage and concentrate. The feeding regimen was ad libitum during lactation and restricted during the dry period according to Danish recommendations (Strudsholm et al., 1999). The cows were inseminated during late May to late June at approximately d 60 (45 to 76) after parturition. Two cows were reinseminated at d 122 and 169, respectively. The cows were dried off $52 \mathrm{~d}$ before expected parturition.

\section{Samplings}

Seven mammary gland biopsies were obtained from each cow. The first biopsy was taken at the end of lactation at $\mathrm{d} 347$ (263 to 455 ), which is equal to $\mathrm{d} 77$ (70 to 82) before expected parturition; the next biopsies were taken during the dry period at $\mathrm{d} 48$ (44 to 57; $4 \mathrm{~d}$ after dry off) and d 16 (11 to 26) before parturition, and again during lactation at d 14 (4 to 35), 42 (34 to 63), 88 (80 to 99), and 172 (164 to 183). Clinical diseases and veterinary treatments were recorded.

The cows were milked immediately before biopsy samples were collected with a Pro-Mag 2.2 instrument and Ultra-Core II needles (Medical Device Technologies, Gainesville, FL) from the central part of front glands. Before sampling, the skin was anesthetized by a subcutaneous injection of $2 \mathrm{~mL}$ of Xylocain $(20 \mathrm{mg} / \mathrm{mL}$ lidocaine, AstraZeneca, Albertslund, Denmark). Two to three biopsies in the same incision were commonly taken. All samples were characterized as parenchyma by visual judgment of the fresh biopsy. The biopsy tissue was either fixed overnight in $4 \%$ neutral buffered formalin before being embedded in paraffin until immunohistochemical analysis, or snap frozen immediately in liquid nitrogen and kept at $-80^{\circ} \mathrm{C}$ until analysis of mRNA abundance.

\section{Real-Time Reverse Transcription PCR}

Sample preparation and quantification of mRNA abundance was carried out as described by Theil et al. (2006). Briefly, mammary tissue was homogenized and RNA was purified using the RNeasy Mini kit (Qiagen, Crawley, UK). Purified RNA was reverse-transcribed using Superscript II RNase H Reverse Transcriptase kit (Invitrogen, Taastrup, Denmark) and a mix of random and Oligo-dT primers, and the cDNA were amplified with TaqMan Universal PCR Master Mix (Applied Biosystems, Naerum, Denmark) using probe and primers specific for each gene (Table 1). Abundance of cJun, plasminogen, ornithine decarboxylase 1 (ODC1) and BCL2-associated X protein (Bax) were detected with locked nucleic acid probes from the human Universal ProbeLibrary (Roche Applied Science, Hvidovre, Denmark), and SYBR Green (Applied Biosystems) was used to detect abundance of $18 \mathrm{~S}$ ribosomal RNA (18S rRNA, reference gene), c-Fos, c-Myc, Akt1, cyclin D1, transforming growth factor $\beta 1$ (TGF- $\beta 1$ ), TGF $\beta$ receptor 1 and 2 (transcript variants 1,2 , and 3; TGFBR1/ 2), tissue plasminogen activator (t-PA), plasminogen activator inhibitor 1 (PAI-1), nuclear factor of kappa light-chain gene enhancer in B-cells 1 (NF $\kappa \mathbf{B 1}), \mathrm{NF} \kappa \mathrm{B}$ inhibitor $\alpha$ (NF $\boldsymbol{\kappa} \mathbf{B I A})$, microsomal glutathione S-transferase 1 (mGST1), tumor necrosis factor receptor superfamily member 6 (Fas), Fas ligand (FasL), caspase-8, caspase-9, signal transducer and activator of transcription 5 (STAT5) A and B, and B-cell leukemia/lymphoma 2 (Bcl-2). Primers were designed by using Primer Express version 2.0 software (Applied Biosystems), and melting curves and controls were used to ensure that primers were specific.

\section{Statistical Analysis and Calculations}

Real-time PCR data were obtained as the number of PCR cycles required to reach a certain threshold (cycle threshold, Ct). Least squares means of $\Delta \mathrm{Ct}$ values $(\Delta \mathrm{Ct}=\mathrm{Ct}$ of the target gene $-\mathrm{Ct}$ of the reference gene $18 \mathrm{~S}$ rRNA) of target genes were normalized to the level observed at $\mathrm{d}-77$ by calculating the $\Delta \Delta \mathrm{Ct}$ values $(\Delta \mathrm{Ct}$ observed at a given stage $-\Delta \mathrm{Ct}$ observed at $\mathrm{d}-77$ ). 
Table 1. Probes and primers used for real-time reverse transcription-PCR on cow mammary gland tissue biopsies

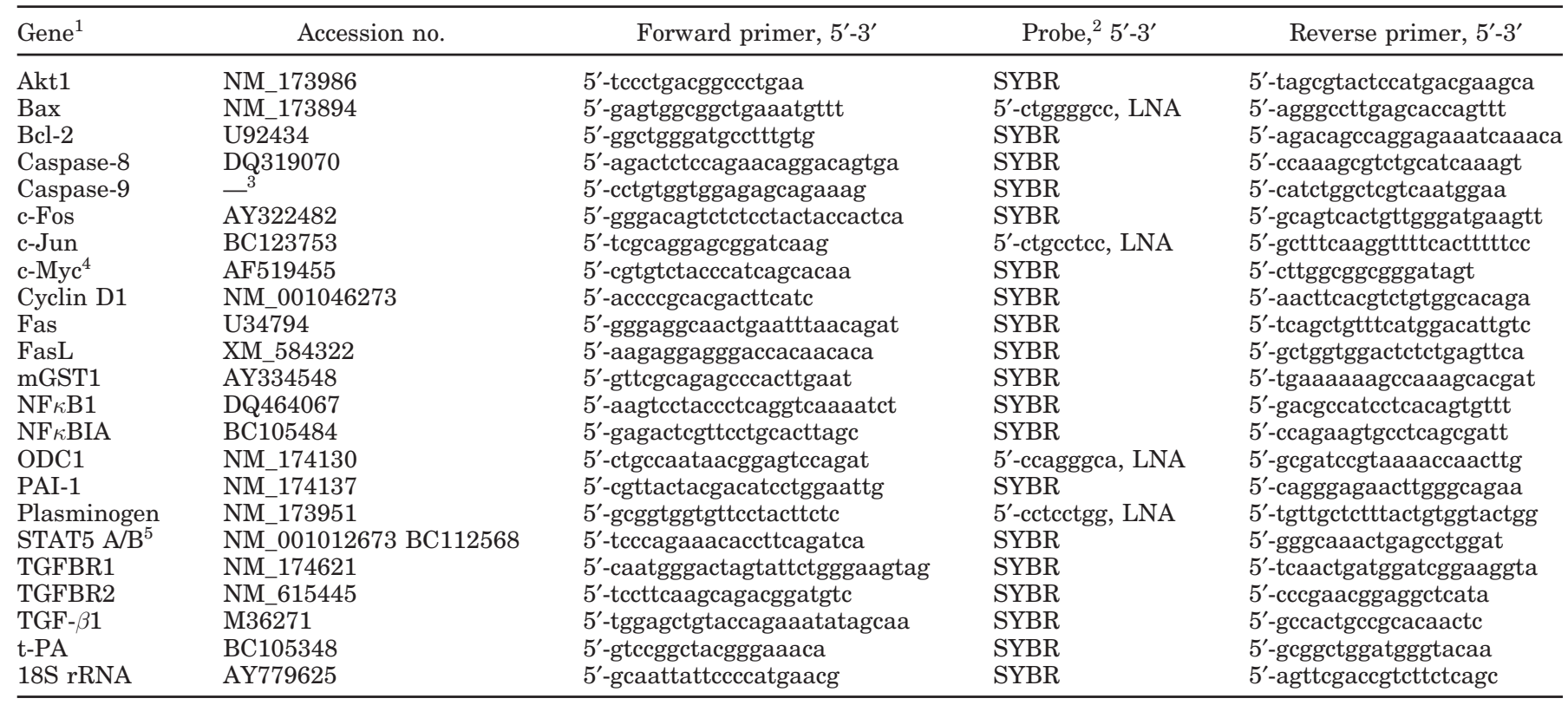

${ }^{1}$ Bax = BCL2-associated X protein; Bcl-2 = B-cell leukemia/lymphoma 2; Fas = tumor necrosis factor receptor superfamily member 6; FasL = Fas ligand; mGST1 = microsomal glutathione S-transferase 1; NF $\kappa \mathrm{B}=$ nuclear factor of kappa light chain gene enhancer in B-cells $1 ; \mathrm{NF} \kappa \mathrm{BIA}=\mathrm{NF} \kappa \mathrm{B}$ inhibitor $\alpha$; ODC1 = ornithine decarboxylase 1; PAI-1 = plasminogen activator inhibitor 1; STAT5 = signal transducer and activator of transcription 5; TGFBR $=$ TGF- $\beta$ receptor 1 and 2 (transcript variant 1,2 and 3 ); TGF- $\beta 1=$ transforming growth factor $\beta$ $1 ; \mathrm{t}-\mathrm{PA}=$ tissue plasminogen activator; $18 \mathrm{~S} \mathrm{rRNA}=18 \mathrm{~S}$ ribosomal RNA.

${ }^{2} \mathrm{SYBR}=\mathrm{SYBR}$ Green nonspecific detection; LNA = locked nucleic acid.

${ }^{3}$ Ensembl transcript ID ENSBTAT00000003205.

${ }^{4}$ Primer sequences are from Musters et al. (2004).

${ }^{5}$ STAT5 primers match both STAT5 A and B isoforms.

The relative mRNA quantity was calculated as $\mathrm{E}^{-\Delta \Delta \mathrm{Ct}}$, where $\mathrm{E}$ is $1+$ PCR efficiency as determined by $10^{-1 /}$ slope of standard curve -1 . In cases with $100 \%$ PCR efficiency, this formula was simplified to: relative quantity = $2^{-\Delta \Delta \mathrm{Ct}}$. All statistics were performed at the $\Delta \mathrm{Ct}$ level (Theil et al., 2006) to exclude potential bias because of averaging data that had been transformed through the equation $2^{-\Delta \Delta \mathrm{Ct}}$. The mRNA quantities were analyzed by using a normal mixed model, and repeated measurements within individual cows were accounted for by specifying a suitable random component. The covariance structure was modeled using the spatial power option, which takes into account the different intervals between repeated measurements. Outliers were removed on the basis of plots of real-time PCR amplification curves, residuals, standardized residuals, and Cook's distance. Data are presented as least squares means with $95 \%$ confidence limits. The contrast statement was used to provide comparisons between stages, such as results obtained during the dry period compared with results obtained during lactation. Differences were considered significant at $P \leq 0.05$.

\section{RESULTS}

Cow health was generally unaffected by biopsy sampling, but 4 cows were treated once for mastitis within $5 \mathrm{~d}$ after sampling and 8 cows received a prophylactic antibiotic treatment at dry off. In total, 6 and 11\% of mammary alveolar cells stained positive for Ki-67 (proliferation) at $\mathrm{d}-48$ and -16 from parturition, respectively. During lactation, Ki-67 staining varied between $0.4 \%$ and $0.9 \%$ (Figure 1). Terminal deoxynucleotidyl transferase dUTP nick-end labeling (TUNEL; apoptosis) of mammary alveolar cells was 0.37 and $0.17 \%$ at $d-48$ and -16 from parturition, respectively. During lactation, TUNEL labeling peaked $(P=0.007)$ at d 14 of lactation with $0.76 \%$ and then dropped to between 0.08 and $0.25 \%$ at later stages (Figure 2).

Table 2 shows mammary cell gene expression in dairy cows during the pregnancy-lactation cycle. The abundance of Fas mRNA was less $(P<0.001)$ during the dry period and did not differ $(P=0.37)$ among stages during lactation. During the dry period, Fas ligand (unlike Fas) showed greater $(P=0.005) \mathrm{mRNA}$ abundance with peak values at $\mathrm{d}-16$ from parturition, but during lacta- 


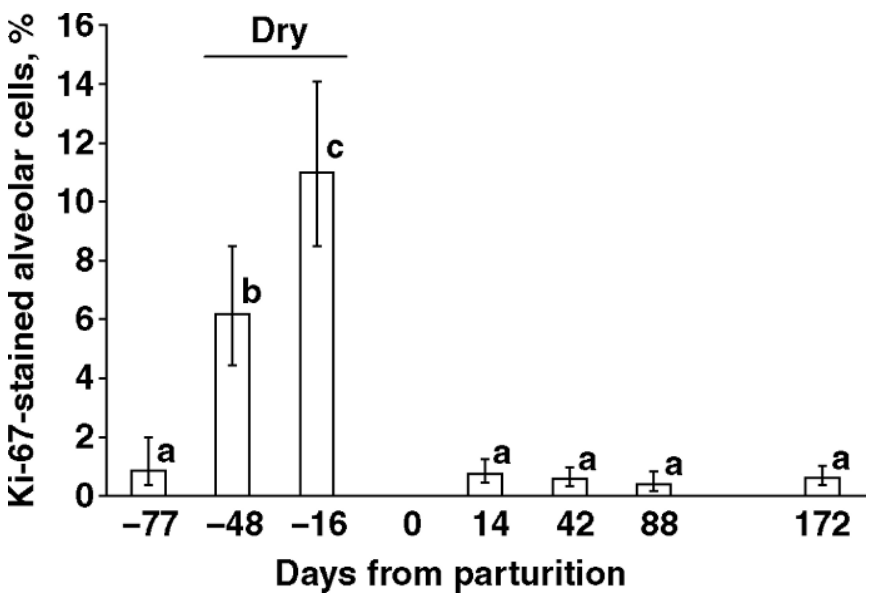

Figure 1. Cell proliferation (Ki-67 staining) of mammary alveolar cells in dairy cows during the pregnancy-lactation cycle. Values are least squares means and 95\% confidence limits; different superscripts indicate significant differences $(P<0.05), \mathrm{n}=7$ to 10 . Data are from Sørensen et al. (2006) using the same biopsies as in the present study.

tion both were unchanged. Abundances of caspase- 8 and caspase-9 mRNA followed a similar pattern, showing tendencies of peak values $(P=0.06$ and 0.11 , respectively) at $d 14$ postpartum.

Abundance of Bcl-2 and Bax mRNA was greatest ( $P$ $<0.001$ ) in the dry period and early lactation, whereas abundance of mGST mRNA did not differ significantly $(P=0.63)$ between measurements.

The early response genes c-Fos, c-Jun, and c-Myc were differently regulated only in the dry period: c-Fos mRNA abundance was greatest $(P<0.001)$ at $\mathrm{d}-48$

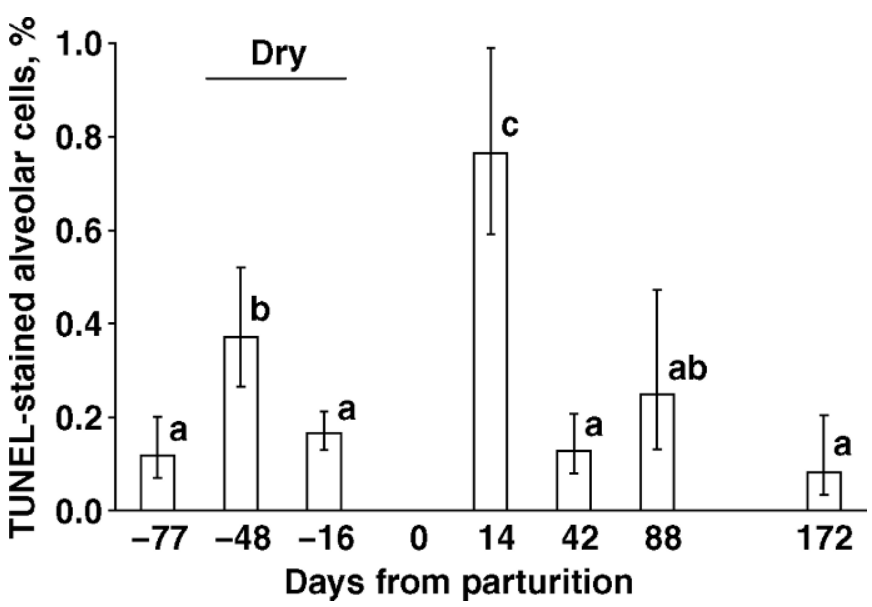

Figure 2. Apoptosis (terminal deoxynucleotidyl transferase dUTP nick-end labeling, TUNEL) of mammary alveolar cells in dairy cows during the pregnancy-lactation cycle. Values are least squares means and $95 \%$ confidence limits; different superscripts indicate significant differences $(P<0.05), \mathrm{n}=7$ to 10 . Data are from Sørensen et al. (2006) using the same biopsies as in the present study. from parturition, c-Jun mRNA abundance was low during the dry period and peaked $(P<0.001)$ at $\mathrm{d} 14$ from parturition, and c-Myc mRNA abundance peaked $(P<$ $0.001)$ at $\mathrm{d}-16$ from parturition and was consistently low and unchanged $(P=0.35)$ during lactation. Abundance of cyclin D1 mRNA was 4 - to 8 -fold greater $(P<$ $0.001)$ at $d-16$ from parturition compared with other stages. The abundance of ODC1 mRNA was greater $(P=0.01)$ in the dry period and early lactation than during other times. The abundance of Akt1 mRNA peaked $(P=0.02)$ at $d 14$ of lactation, and was relatively constant at other stages.

Abundance of $\mathrm{NF} \kappa \mathrm{B}$ and $\mathrm{NF} \kappa \mathrm{BIA}$ mRNA was greatest $(P=0.04$ and 0.08 , respectively) in biopsies taken at $\mathrm{d}-16$ and 14 from parturition, and their mRNA abundance showed the same pattern over time. The abundance of TGF- $\beta$ mRNA did not change during the pregnancy-lactation cycle. The 2 TGF- $\beta$ receptors TGFBR 1 and 2 showed the same pattern of mRNA abundance with 2 -fold greater $(P=0.01)$ abundance at d 14 compared with d -16 and d 42 from parturition.

A 3 -fold $(P<0.001)$ increase was found in STAT5 mRNA abundance from $\mathrm{d}-48$ to -16 from parturition. Abundance of STAT5 mRNA remained elevated at d 14 of lactation and generally was less $(P=0.005)$ at later stages of lactation. Low mRNA abundance and great variability was found for plasminogen mRNA and thus no significant differences could be obtained. Abundance of t-PA mRNA tended to be greater $(P=0.11)$ at $\mathrm{d}$ 14 of lactation and for PAI-1, mRNA abundance was greatest $(P<0.001)$ during dry period and early lactation. Compared with d 14 of lactation, PAI-1 mRNA abundances were lower $(P=0.01)$ and t-PA mRNA abundance tended $(P=0.10)$ to be lower at the later stages of lactation.

\section{DISCUSSION}

Because mammary cell number accounts for some of the variation in milk yield during the lactation cycle, it is important to maintain high cell numbers by either increasing mammary cell survival and proliferation or reducing apoptosis. As illustrated in Figures 1 and 2, large variations are observed during the pregnancylactation cycle in the rates of cell proliferation and apoptosis. The molecular mechanisms underlying the regulation of these processes are numerous, and in the present study, we have chosen to focus on a few mechanisms by describing the regulation of genes encoding proteins with known impact on cell turnover.

\section{Pathways in Apoptosis}

The peak values for apoptosis occurred at $d-48$ and d 14 from parturition as previously reported for these 
Table 2. Mammary cell gene expression in dairy cows during the pregnancy-lactation cycle ${ }^{1}$

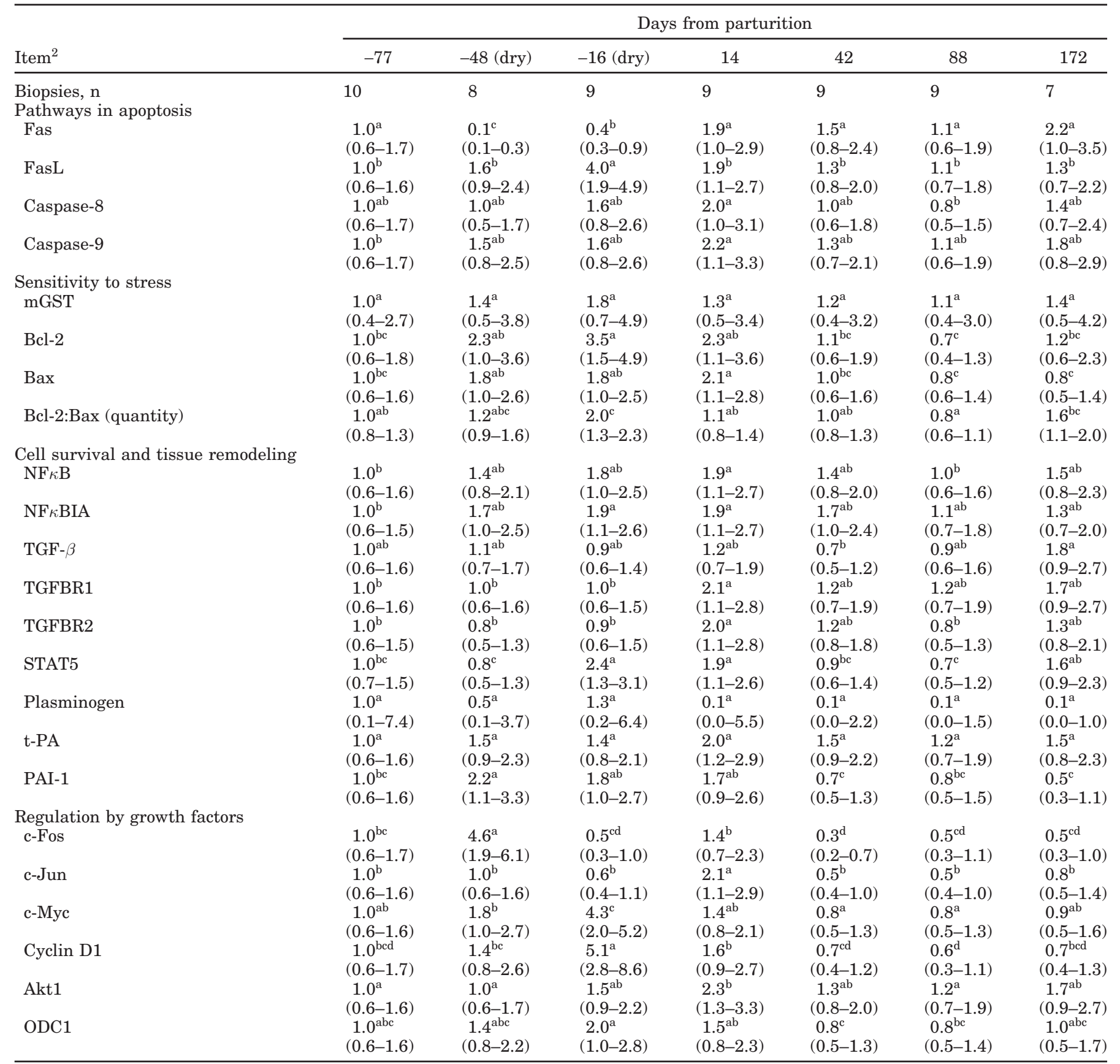

\footnotetext{
${ }^{\mathrm{a}-\mathrm{d}}$ Different superscripts within a row indicate significantly $(P<0.05)$ different means between days.

${ }^{1}$ mRNA abundance relative to $\mathrm{d}-77$ from parturition and based on least squares means. Day -77 corresponds to $\mathrm{d} 347$ of lactation. Values in parentheses are $95 \%$ confidence limits.

${ }^{2}$ Fas $=$ tumor necrosis factor receptor superfamily member 6 ; FasL = Fas ligand; $\mathrm{mGST}=$ microsomal glutathione $\mathrm{S}$-transferase $1 ; \mathrm{NF} \kappa \mathrm{B}=$ nuclear factor of kappa light chain gene enhancer in B-cells; NF $\kappa \mathrm{BIA}=\mathrm{NF} \kappa \mathrm{B}$ inhibitor $\alpha$; TGF- $\beta=$ transforming growth factor $\beta 1$; TGFBR $=$ TGF $-\beta$ receptor 1 and 2; STAT5 = signal transducer and activator of transcription $5 \mathrm{~A}$ and $\mathrm{B}$; $\mathrm{t}-\mathrm{PA}=$ tissue plasminogen activator; PAI- $1=$ plasminogen activator inhibitor 1 ; ODC $=$ ornithine decarboxylase 1.
} 
samples in Sørensen et al. (2006). The high level of apoptosis in early lactation might serve to discard nonfunctional and senescent cells or to remove an excess capacity of newly synthesized cells (Sørensen et al., 2006). The most important death receptor in regulation of apoptosis initiated by extrinsic factors is Fas (Ozoren and El Deiry, 2003). The Fas ligand can be produced by activated T cells or by the mammary cells themselves in an autoapoptotic-inducing manner (Maher et al., 2002). The gene expression of Fas was lowest at $d-48$ from parturition, when apoptosis was high. Based on this observation, our data suggest that the extrinsic pathway of apoptosis does not play a major role at this stage. On the other hand, FasL gene expression showed the opposite pattern to Fas gene expression, thus counteracting the low receptor expression.

The interaction of Fas-FasL leads to activation of caspase- 8 , and subsequently caspase- 3 , resulting in activation of DNA-degrading enzymes (Maher et al., 2002). The intrinsic pathway of apoptosis is initiated by the cytochrome $\mathrm{c}$ release from the mitochondria and results in caspase-9 activation of caspase-3 (Waterhouse et al., 2002). The ratios of caspase- 8 and caspase9 to caspase- 3 can be an indicator of which pathway, extrinsic or intrinsic, may be initiating apoptosis (Atapattu and Czuprynski, 2005). Gene expression patterns of caspase- 8 and caspase-9 did not differ during the lactation-pregnancy cycle. This indicates that no change in the prevalence of the major classes of pathways leading to apoptosis was prevailing at a given stage, although it should be taken into account that the caspases are translated as procaspases, needing activation to mediate any biological effect.

\section{Sensitivity to Mitochondrial Stress}

The intrinsic pathways leading to apoptosis can be initiated by cytochrome c release from the mitochondria, which function as universal stress sensors (Kroemer, 2003). Stimuli for initiating apoptosis can be the reactive oxygen species, continuously produced as by-products from the mitochondrial respiratory chain. Mitochondrial glutathione (GSH) is utilized in the process of neutralizing these agents (Fernandez-Checa, 2003). The level of GSH can be regarded as a marker of cell vulnerability to stress factors. Glutathione Stransferase mRNA (mGST) is an indicator of GSH synthesis (Colitti et al., 2005). We expected high expression of the mGST gene in early to mid-lactation, due to high mitochondrial activity. However, gene expression of mGST did not change significantly during the pregnancy-lactation cycle.

Another indicator of sensitivity of cells for undergoing apoptosis is the ratio between Bcl-2 and Bax (Schultz and Harrington, 2003). Bax is a proapoptotic factor located in the cytoplasm, and upon apoptotic stimuli, Bax is translocated into the mitochondrial membrane mediating cytochrome $\mathrm{c}$ release and apoptosis (Smaili et al., 2003). Bcl-2 is consumed by the interaction with Bax, inhibiting Bax membrane oligomerization (Dlugosz et al., 2006). In dairy cows (Annen et al., 2007) and sheep (Nørgaard et al., 2008), the Bcl-2 to Bax ratio is greater in late pregnancy than in early lactation. In the present study the Bcl-2 to Bax mRNA quantity ratio was greatest $(P=0.003)$ at $\mathrm{d}-16$ from parturition. This coincided with the highest level of cell proliferation and a low rate of apoptosis.

\section{Cell Survival and Tissue Remodeling}

To describe the regulation of factors with well-established effects on cell viability, we measured expression of genes in the NF- $\kappa \mathrm{B}$ and TGF- $\beta$ system. In the cytoplasm, inactive NF- $\kappa \mathrm{B}$ exists in complex with its inhibitor, $\mathrm{NF} \kappa \mathrm{BIA}$. Upon stimuli from the TNF-receptor signal transduction pathway, $\mathrm{NF} \kappa \mathrm{BIA}$ is degraded and $\mathrm{NF}-\kappa \mathrm{B}$ is released. This allows NF- $\kappa \mathrm{B}$ to be translocated to the nucleus, where it can induce gene expression of survival factors, which are able to inhibit and counteract factors leading to apoptosis (Schultz and Harrington, 2003). Gene expression of $\mathrm{NF} \kappa \mathrm{B}$ and $\mathrm{NF} \kappa \mathrm{BIA}$ showed only minor variations during the pregnancylactation cycle with slightly increased expression in the late dry period and in early lactation compared with later stages of lactation. An increase in active $\mathrm{NF} \kappa \mathrm{B}$ at the stages where we observed increased $\mathrm{NF}-\kappa \mathrm{B}$ gene expression corresponds well to the pattern of mammary IGF-I gene expression (Sørensen et al., 2006) and an anticipated need for survival factors in the late dry period and early lactation. However, it is difficult to predict the importance of $\mathrm{NF} \kappa \mathrm{B}$ gene expression because activation depends on degradation of $\mathrm{NF} \kappa \mathrm{BIA}$.

Gene expression of TGF- $\beta 1$ and its 2 receptors were studied to investigate if their expression patterns corresponded to that of mammary gland cell turnover and tissue remodeling. Transforming growth factor $\beta 1$ often mediates cell cycle arrest in the G1 phase, and TGF$\beta 1$ signaling occurs by binding of TGF- $\beta 1$ to TGFBR2, which activates and binds to the structurally similar TGFBR1.

It is not clear how important TGF- $\beta 1$ is for cell turnover in the mammary gland during the pregnancy-lactation cycle in multiparous cows. In prepubertal heifers, TGF- $\beta 1$ stimulates proliferation of mammary stromal cells but not epithelial cells (Musters et al., 2004), in which TGF- $\beta 1$ is found to induce apoptosis by inhibiting cell survival pathways (Gajewska and Motyl, 2004). In tissue from pubertal heifers, TGF- $\beta 1$ stimulated DNA 
synthesis at low concentrations but inhibited DNA synthesis at greater concentrations (Purup et al., 2000). Recently, Zarzynska et al. (2007) found that mammary expression of TGF- $\beta 1$ and TGFBR2 coincided with apoptosis.

In dairy cows, TGF- $\beta 1$ membrane binding (Plaut and Maple, 1995), expression of TGF- $\beta 1$ and TGFBR2 (Zarzynska et al., 2007), and TGF- $\beta 1$ mRNA abundance (Plath et al., 1997) are found to be low during early stages of lactation and high during mammary gland development and involution. The same findings are repeated in goats (Wareski et al., 2001). Our results for TGF- $\beta 1$ and TGFBR 1 and 2 gene expression are not in agreement with these observations. Interestingly, we find a pattern of TGFBR 1 and 2 gene expression opposite to the pattern of TGF- $\beta 1$ binding to mammary membranes found by Plaut and Maple (1995). Those authors found low TGF- $\beta 1$ membrane binding at $\mathrm{d} 7$ of lactation, whereas we observed a peak in TGFBR 1 and 2 gene expressions at d 14 of lactation. Plaut and Maple (1995) explained their finding with a concurrent low level of apoptosis based on findings in mouse mammary glands. However, we recently found that apoptosis in dairy cows is elevated in early lactation (Sørensen et al., 2006), and thus the increased mammary TGFBR 1 and 2 gene expression coincides with apoptosis in early lactation.

The signal transduction pathways of prolactin and growth hormone involve activation of STAT5. The role of STAT5 is critical for cell proliferation, survival and differentiation in mouse mammary gland during pregnancy (Cui et al., 2004). In the bovine mammary gland, the effects of STAT5 are not clear. We observed a significant increase in STAT5 mRNA at d -16 and $\mathrm{d} 14$ from parturition. This is in accordance with a study on cows showing STAT5 DNA binding activity and STAT5 phosphorylation at near-maximal levels at -27 to -35 $\mathrm{d}$ from parturition and high levels on the day of calving (Wheeler et al., 2001). High growth hormone concentrations are found during early lactation (Sørensen et al., 2006). Furthermore, early lactation coincided with spring and early summer, which might have stimulated prolactin levels (Dahl et al., 2000). Thus, both growth hormone and prolactin concentrations were potentially greatest during early lactation, when epithelial cell differentiation occurs in dairy cows (Capuco et al., 2001). Thus, both STAT5 gene expression and STAT5 activity imply a role in mammary cell proliferation and differentiation in cows.

The plasmin-associated genes were evaluated to describe how their gene expression compares to cell turnover. Plasmin initiates activation of matrix metalloproteinases resulting in tissue remodeling. The activation of plasminogen by t-PA and urokinase-PA to plasmin can be inhibited by PAI-1 (Politis, 1996). Degradation of the extracellular matrix initiated by plasmin is correlated to cell proliferation (Politis, 1996) and to involution/apoptosis (Tonner et al., 2000). IGF binding protein (BP)-5 enhances the activity of t-PA by inhibiting PAI1 and directly stimulating t-PA (Sorrell et al., 2006), thus indirectly activating plasminogen to plasmin. We observed the greatest IGFBP-5 gene expression (Sørensen et al., 2006) and a tendency of a peak in tPA gene expression at $d 14$ of lactation coinciding with a peak in apoptosis. Furthermore, PAI-1 gene expression was greatest during the dry period and early lactation coinciding with high rates of cell proliferation and apoptosis. This may, as proposed by others (Tonner et al., 2000; Flint et al., 2005), indicate that IGFBP-5 has a dual role by reducing the availability of the survival factor IGF-I as well as increasing extracellular matrix degradation, thereby coordinating apoptosis and tissue remodeling. However, although a relatively high level of apoptosis is found in early lactation in cows, it is still uncertain to which degree tissue remodeling occurs in early lactation.

\section{Regulation by Growth Factors}

Gene expression of c-Fos, c-Myc, and cyclin D1 but not c-Jun, ODC1, or Akt1 were increased during the dry period. Growth factors initiate posttranslational modification of transcription factors for the early response genes such as c-Fos, c-Jun, and c-Myc. These early-response genes induce transcription of other factors such as the cyclin Ds, thereby initiating cell cycle progression (Sherr, 1995). Insulin and IGF-I plasma concentrations are increased during the dry period (Sørensen et al., 2006) coinciding with the high cell proliferation, but for unknown reasons, this did not relate to the expression pattern of early response genes.

Ornithine decarboxylase is a rate-limiting enzyme in polyamine synthesis, which is required for cell proliferation as well as other processes (Kim and Park, 2004). Transcription of ODC1 is initiated by c-Myc (Vermeulen et al., 2003) and it is stimulated by high nutritional level and elevated during phases with rapid mammary growth and differentiation (Kim and Park, 2004). This agrees with our observations on ODC1 gene expression in the dry period and early lactation, although gene expression was only increased 1.5- to 2-fold compared with other stages of the pregnancy-lactation cycle.

The abundance of Akt1 mRNA was greatest at d 14 of lactation and thus similar to gene expression of IGFI and type I IGF receptor (Sørensen et al., 2006). Growth factor-activated Akt is central in regulating cell survival, apoptosis, and proliferation as well as metabolism and cell growth (Fayard et al., 2005). Hence, Akt1 tran- 
scription concurs with ongoing differentiation in early lactation (Capuco et al., 2001), but not with increased apoptosis in early lactation.

\section{CONCLUSIONS}

According to gene expression of the indicators for pathways leading to apoptosis, no shift between the extrinsic and intrinsic pathways occurred during the pregnancy-lactation cycle. Mammary cell apoptosis could not be related to mGST gene expression, but the ratio between Bcl-2 and Bax was greatest in late dry period, when cell proliferation is high and apoptosis low. Over time, the $\mathrm{NF} \kappa \mathrm{B}$ system only showed minor variation in gene expression. Changes in gene expression of the TGF- $\beta$ system did not correlate well to changes in cell turnover, but gene expression of both STAT5 and the genes in the plasmin system pointed to a role in regulation of mammary cell turnover. Gene expression of growth factor-induced early response genes did not correlate well with cell proliferation.

\section{ACKNOWLEDGMENTS}

This study was partly financed by the Research School of Animal Nutrition and Physiology, Faculty of Life Sciences, Copenhagen University, Denmark.

\section{REFERENCES}

Annen, E. L., A. C. Fitzgerald, P. C. Gentry, M. A. McGuire, A. V. Capuco, L. H. Baumgard, and R. J. Collier. 2007. Effect of continuous milking and bovine somatotropin supplementation on mammary epithelial cell turnover. J. Dairy Sci. 90:165-183.

Atapattu, D. N., and C. J. Czuprynski. 2005. Mannheimia haemolytica leukotoxin induces apoptosis of bovine lymphoblastoid cells (BL-3) via a caspase-9-dependent mitochondrial pathway. Infect. Immun. 73:5504-5513.

Capuco, A. V., D. L. Wood, R. Baldwin, K. Mcleod, and M. J. Paape. 2001. Mammary cell number, proliferation, and apoptosis during a bovine lactation: Relation to milk production and effect of bST. J. Dairy Sci. 84:2177-2187.

Colitti, M., G. Stradaioli, and B. Stefanon. 2005. Mammary cell turnover in lactating ewes is modulated by changes of energy fuels. Res. Vet. Sci. 78:53-59.

Cui, Y., G. Riedlinger, K. Miyoshi, W. Tang, C. L. Li, C. X. Deng, G. W. Robinson, and L. Hennighausen. 2004. Inactivation of Stat5 in mouse mammary epithelium during pregnancy reveals distinct functions in cell proliferation, survival, and differentiation. Mol. Cell. Biol. 24:8037-8047.

Dahl, G. E., B. A. Buchanan, and H. A. Tucker. 2000. Photoperiodic effects on dairy cattle: A review. J. Dairy Sci. 83:885-893.

Dlugosz, P. J., L. P. Billen, M. G. Annis, W. J. Zhu, Z. Zhang, J. L. Lin, B. Leber, and D. W. Andrews. 2006. Bcl-2 changes conformation to inhibit Bax oligomerization. EMBO J. 25:2287-2296.

Fayard, E., L. A. Tintignac, A. Baudry, and B. A. Hemmings. 2005. Protein kinase B/Akt at a glance. J. Cell Sci. 118:5675-5678.

Fernandez-Checa, J. C. 2003. Redox regulation and signaling lipids in mitochondrial apoptosis. Biochem. Biophys. Res. Commun. 304:471-479.

Flint, D. J., M. Boutinaud, E. Tonner, C. J. Wilde, W. Hurley, P. A. Accorsi, A. F. Kolb, C. B. A. Whitelaw, J. Beattie, and G. J. Allan.
2005. Insulin-like growth factor binding proteins initiate cell death and extracellular matrix remodeling in the mammary gland. Domest. Anim. Endocrinol. 29:274-282.

Gajewska, M., and T. Motyl. 2004. IGF-binding proteins mediate TGF-beta 1-induced apoptosis in bovine mammary epithelial BME-UV1 cells. Comp. Biochem. Physiol. C 139:65-75.

Kim, H. H., and C. S. Park. 2004. A compensatory nutrition regimen during gestation stimulates mammary development and lactation potential in rats. J. Nutr. 134:756-761.

Kroemer, G. 2003. Mitochondrial control of apoptosis: An introduction. Biochem. Biophys. Res. Commun. 304:433-435.

Maher, S., D. Toomey, C. Condron, and D. Bouchier-Hayes. 2002. Activation-induced cell death: The controversial role of Fas and Fas ligand in immune privilege and tumour counterattack. Immunol. Cell Biol. 80:131-137.

Musters, S., K. Coughlan, T. McFadden, R. Maple, T. Mulvey, and K. Plaut. 2004. Exogenous TGF-beta 1 promotes stromal development in the heifer mammary gland. J. Dairy Sci. 87:896-904.

Nørgaard, J. V., M. O. Nielsen, P. K. Theil, M. T. Sorensen, S. Safayi, and K. Sejrsen. 2008. Development of mammary glands of fat sheep submitted to restricted feeding during late pregnancy. Small Rumin. Res. 76:155-165.

Nørgaard, J., A. Sorensen, M. T. Sørensen, J. B. Andersen, and K. Sejrsen. 2005. Mammary cell turnover and enzyme activity in dairy cows: Effects of milking frequency and diet energy density. J. Dairy Sci. 88:975-982.

Nøgaard, J. V., M. T. Sorensen, P. K. Theil, J. Sehested, and K. Sejrsen. 2008. Effect of pregnancy and feeding level on cell turnover and expression of related genes in the mammary tissue of lactating dairy cows. Animal 2:588-594.

Ozoren, N., and W. S. El Deiry. 2003. Cell surface death receptor signaling in normal and cancer cells. Semin. Cancer Biol. 13:135-147.

Plath, A., R. Einspanier, F. Peters, F. Sinowatz, and D. Schams. 1997. Expression of transforming growth factors alpha and beta1 messenger RNA in the bovine mammary gland during different stages of development and lactation. J. Endocrinol. 155:501-511.

Plaut, K., and R. L. Maple. 1995. Characterization of binding of transforming growth-factor-beta-1 to bovine mammary membranes. J. Dairy Sci. 78:1463-1469.

Politis, I. 1996. Plasminogen activator system: Implications for mammary cell growth and involution. J. Dairy Sci. 79:1097-1107.

Purup, S., M. Vestergaard, M. S. Weber Nielsen, K. Plaut, R. M. Akers, and K. Sejrsen. 2000. Local regulation of pubertal mammary growth in heifers. J. Anim. Sci. 78(Suppl. 3):36-47.

Schultz, D. R., and W. J. Harrington. 2003. Apoptosis: Programmed cell death at a molecular level. Semin. Arthritis Rheum. $32: 345-369$.

Sherr, C. J. 1995. D-Type Cyclins. Trends Biochem. Sci. 20:187-190.

Smaili, S. S., Y. T. Hsu, A. C. P. Carvalho, T. R. Rosenstock, J. C. Sharpe, and R. J. Youle. 2003. Mitochondria, calcium and proapoptotic proteins as mediators in cell death signaling. Braz. J. Med. Biol. Res. 36:183-190.

Sørensen, M. T., J. V. Nørgaard, P. K. Theil, M. Vestergaard, and K. Sejrsen. 2006. Cell turnover and activity in mammary tissue during lactation and the dry period in dairy cows. J. Dairy Sci. 89:4632-4639.

Sorrell, A. M., J. H. Shand, E. Tonner, M. Gamberoni, P. A. Accorsi, J. Beattie, G. J. Allan, and D. J. Flint. 2006. Insulin-like growth factor-binding protein-5 activates plasminogen by interaction with tissue plasminogen activator, independently of its ability to bind to plasminogen activator inhibitor-1, insulin-like growth factor-I, or heparin. J. Biol. Chem. 281:10883-10889.

Strudsholm, F., O. Aaes, J. Madsen, V. Friis Kristensen, H. Refsgaard Andersen, T. Hvelplund, and S. Østergaard. 1999. Danish Nutrient Recommendations for Cattle. Report no.84, The Danish Agricultural Advisory Centre, Skejby, Denmark.

Theil, P. K., I. L. Sorensen, M. Therkildsen, and N. Oksbjerg. 2006. Changes in proteolytic enzyme mRNAs relevant for meat quality during myogenesis of primary porcine satellite cells. Meat Sci. 73:335-343. 
Tonner, E., G. J. Allan, and D. J. Flint. 2000. Hormonal control of plasmin and tissue-type plasminogen activator activity in rat milk during involution of the mammary gland. J. Endocrinol. 167:265-273.

Vermeulen, K., Z. N. Berneman, and D. R. Van Bockstaele. 2003. Cell cycle and apoptosis. Cell Prolif. 36:165-175.

Wareski, P., T. Motyl, Z. Ryniewicz, A. Orzechowski, B. Gajkowska, U. Wojewodzka, and T. Ploszaj. 2001. Expression of apoptosisrelated proteins in mammary gland of goat. Small Rumin. Res. 40:279-289.
Waterhouse, N. J., J. E. Ricci, and D. R. Green. 2002. And all of a sudden it's over: Mitochondrial outer-membrane permeabilization in apoptosis. Biochimie 84:113-121.

Wheeler, T. T., M. K. Broadhurst, H. B. Sadowski, V. C. Farr, and C. G. Prosser. 2001. Stat5 phosphorylation status and DNA-binding activity in the bovine and murine mammary glands. Mol. Cell. Endocrinol. 176:39-48.

Zarzynska, J., B. Gajkowska, U. Wojewodzka, E. Dymnicki, and T. Motyl. 2007. Apoptosis and autophagy in involuting bovine mammary gland is accompanied by up-regulation of TGF-beta(1) and suppression of somatotropic pathway. Pol. J. Vet. Sci. 10:1-9. 